\title{
Immune Response of Broilers Fed Conventional and Alternative Diets Containing Multi-Enzyme Complex
}

\section{nAuthor(s)}

Montanhini Neto $\mathrm{R}^{1}$

Ceccantini $\mathrm{ML}^{1}$

Fernandes $\mathrm{JIM}^{2}$

Adisseo Brazil Animal Nutrition Ltd.

2 Federal University of Paraná, Palotina campus

\section{Mail Adress}

Corresponding author e-mail address Adisseo Brazil Animal Nutrition Ltd., Avenida Maria Coelho Aguiar, n. 215, CENESP, Bloco G, $1^{\circ}$ andar, Zip Code 05.804-900, São Paulo, São Paulo, Brazil. Phone: +55 4191161820.

E-mail: roberto.neto@adisseo.com

\section{घKeywords}

Carbohydrases, non-starch polysaccharides, fibrous brans.

\section{ABSTRACT}

The present study aimed at evaluating the effect of adding a commercial multi-enzyme complex to conventional and alternative broiler diets on the immune response and occurrence of lesions in the intestinal mucosa. In total, 900 male broiler chicks were distributed according to a completely randomized design, with six treatments of six replicates each. Two control diets were formulated: one with conventional feedstuffs (T1), based on corn and soybean meal, and one with alternative feedstuffs (T4), containing corn, millet, and soybean, canola and sunflower meals. Based on these diets, other four were prepared with reduced metabolizable energy, digestible amino acids, calcium and available phosphorus levels and the addition (T3 and T6) or not (T2 and T5) of a multi-enzyme complex. Broilers fed diets based on conventional feedstuffs had higher levels of defense cells compared with those fed diets that included millet with canola and sunflower meals. On the other hand, the use of enzymes in conventional or alternative diets decreased the number of these cells in the ileal mucosa.

\section{INTRODUCTION}

The quality of feedstuffs for feed production can be highly variable, especially considering their nutritional composition (Maisonnier et al., 2001). Antinutritional factors and non-starch polysaccharides (NSP) in plant ingredients that make up the diet may have negative effects on the gut health and performance of poultry and pigs (Farrell, 2005; Jia et al., 2009). NSP are the main constituents of the cell wall of plant cells, but cannot be digested by poultry due to the nature of the chemical bonds that resist to hydrolysis in the digestive tract (Ramos et al., 2007). Monogastric animals are not able to digest cellulose, arabinoxylans, beta-glucans, pectins, and other NSPs (Fang et al., 2007).

The inability to digest fiber, in addition of reducing feed energy value, can impair the use of all other nutrients. This is especially the case of soluble fibers, which present high capacity to absorb water and gelatinize the ingesta in the intestinal tract (Choct et al., 2010). This increased viscosity of the intestinal chime slows the passage of feed along the digestive tract, makes it difficult the dispersion and action of endogenous enzymes and negatively interferes with the diffusion or transport of nutrients by enterocytes (Choct et al., 2004). Moreover, the utilization of dietary fats may be impaired due to the decrease in emulsification and conjugation of bile salts with these compounds (Campbell et al., 1983).

In addition to digestion impairment caused by intestinal flow conditions induced by NSP, the presence of undigested fiber fragments negatively contributes to the inflammatory status of the enteric mucosa (Lentle \& Janssen, 2008). The intake of NSP-rich ingredients promotes 
epithelial apoptosis along crypts and villi, villus fusion and increase in number and cytoplasmic extension of goblet cells, making the mucus layer of the epithelial lining of the intestinal mucosa thicker (Lentle et al., 2007). When injury occurs, there is a disruption of the intestinal dynamics that, in addition of reducing the amount of digested and absorbed substrate, also increases the metabolic cost for the recovery of the damaged tissue. Thus the regeneration of the intestinal mucosa is a costly and time-consuming process, which may take 96 hours that represents between 8 and $9 \%$ of the lifetime of a broiler (Macari et al., 2002).

Diets with alternative plant feedstuffs, which are usually NSP-rich, also stimulate the replication of the microbial population in the intestinal lumen, elevating the fermentation rate and the risk of producing bacterial enterotoxins. The colonization by bacteria is favored by the increase in substrates that are not used by the animals and become available for the multiplication of microorganisms (Högberg \& Lindberg, 2004). The shift in microbial populations can damage the mucosa and increase the infiltration of immune cells in the intestinal tract of poultry (Teirlynck et al., 2009). Experiments have shown that some abrasive NSP, by breaking cells of the intestinal mucosa, stimulate the innate immune system and increase the proliferation of macrophages and monocytes at the site, resulting in cytokine production (Peng et al., 1991; Zhang \& Tizzard, 1996; Ross et al., 2002). The nutritional and metabolic cost to support an immune response in broilers is high and inversely correlated with growth performance (Humphrey \& Klasing, 2007).

The addition of exogenous enzymes to diets can used as a strategy to improve the utilization of NPSrich ingredients (Kocher et al., 2000; Montanhini et al., 2012). Enzymes hydrolyze NSP from plant ingredients and improve the production efficiency of animals by increasing the digestion of low-quality products and reducing nutrient loss via feces (Kim et al., 2005; Shirmohammad \& Mehr, 2011). By calculating this reduction of losses with the better utilization of dietary nutrients, it is possible to decrease the dietary level of nutrients, making cheaper feed, without compromising the broiler performance (Meng et al., 2005).

Another benefit of using these enzymes is the reduction of intestinal digesta viscosity by changing the intestinal microbiota and reducing the adverse effects of microbial fermentation in the small intestine. This effect can also reduce excreta moisture, which improves litter quality and increases nutrient diffusion rates (Oliveira \& Moraes, 2007; Lee et al., 2010). The degradation of NSP present in the plant cell wall by the action of exogenous enzymes increases the levels of substrate available for microbial fermentation in the cecum and the production of short chain fatty acids, which can be used by broilers as a source of energy (Choct et al., 1996; Steenfeldt et al., 1998).

Nevertheless, the addition of exogenous enzymes or enzyme complexes can sometimes render controversial results. The enzyme should be specific and supplied in an amount proportional to the substrate, but the determination of the amount of NSP present in feed hinders its inclusion (Rutherfurd et al., 2007; Woyengo et al., 2010). Furthermore, the enzyme should remain stable during and after feed processing until its consumption and in the intestinal environment where it will act (Odetallah et al., 2002).

The present study aimed at evaluating the effect of adding a commercial multi-enzyme complex to diets made up by conventional and alternative plant ingredients, with reduced nutritional density, on the immune response and occurrence of intestinal injury in broilers.

\section{MATERIAL AND METHODS}

The experiment was conducted in the experimental poultry house of the Federal University of Paraná, campus of Palotina, Paraná State, Southern Brazil, with the approval of the Ethics Committee on the Use of Animals in Experimentation from the UFPR/Palotina, protocol \#13/2010 of March 14, 2010.

Nine-hundred one-day-old male broiler chicks (Cobb Slow commercial line) from the same breeder flock were distributed according to a completely randomized design into six treatments with six replicates of 25 chicks each, comprising 36 experimental units.

Treatments were divided as follows: $T 1$, conventional control diet based on corn and soybean meal; T2, conventional diet with reduced nutritional density; T3, T2 diet with the addition of a commercial multienzyme complex composed of carbohydrolases and phytase (Rovabio MAX AP, Adisseo France SAS); T4, alternative control diet with the same nutritional levels as T1, containing corn, millet, and soybean, canola and sunflower meals; T5, alternative diet with reduced nutritional density; and T6, T5 diet with the addition of the above-mentioned commercial multi-enzyme complex.

With the purpose of further discussing the results, the contrasts between the inclusion of the enzyme 
Table 2 - Composition and nutritional levels of the starter diets.

\begin{tabular}{|c|c|c|c|c|c|c|}
\hline Ingredients & $\mathrm{T} 1$ * & $\mathrm{T} 2$ & T3 & T4 & T5 & T6 \\
\hline Corn & 50.32 & 53.26 & 53.26 & 28.83 & 31.26 & 31.26 \\
\hline Millet & - & - & - & 14.38 & 15.60 & 15.60 \\
\hline Soybean meal & 41.45 & 40.08 & 40.08 & 30.69 & 29.46 & 29.46 \\
\hline Sunflower meal & - & - & - & 7.67 & 7.37 & 7.37 \\
\hline Canola meal & - & - & - & 7.67 & 7.37 & 7.37 \\
\hline Soybean oil & 4.05 & 3.00 & 3.00 & 6.58 & 5.28 & 5.28 \\
\hline Limestone & 1.04 & 1.23 & 1.23 & 0.99 & 1.19 & 1.19 \\
\hline Dicalcium phosphate & 1.73 & 0.90 & 0.90 & 1.61 & 0.80 & 0.80 \\
\hline Salt & 0.46 & 0.47 & 0.47 & 0.46 & 0.46 & 0.46 \\
\hline L-Lysine 78\% & 0.16 & 0.17 & 0.17 & 0.32 & 0.32 & 0.32 \\
\hline DL-Methionine 99\% & 0.33 & 0.33 & 0.33 & 0.30 & 0.29 & 0.29 \\
\hline L-Threonine 98\% & 0.06 & 0.06 & 0.06 & 0.10 & 0.10 & 0.10 \\
\hline Multi-enzyme complex ** & - & - & 0.10 & - & - & 0.10 \\
\hline Inert material & - & 0.10 & - & - & 0.10 & - \\
\hline Vitamin and Mineral Premix*** & 0.40 & 0.40 & 0.40 & 0.40 & 0.40 & 0.40 \\
\hline Metabolizable Energy (kcal/kg) & 3.050 & 2.965 & 2.965 & 3.050 & 2.965 & 2.965 \\
\hline Crude Protein (\%) & 22.78 & 21.97 & 21.97 & 22.20 & 21.76 & 21.76 \\
\hline Crude Fiber (\%) & 3.08 & 3.06 & 3.06 & 5.13 & 5.07 & 5.07 \\
\hline Crude Fat (\%) & 6.33 & 5.37 & 5.37 & 7.77 & 6.23 & 6.23 \\
\hline Digestible Lysine (\%) & 1.18 & 1.16 & 1.16 & 1.18 & 1.16 & 1.16 \\
\hline Digestible Met + Cis (\%) & 0.86 & 0.84 & 0.84 & 0.86 & 0.84 & 0.84 \\
\hline Digestible Threonine (\%) & 0.76 & 0.74 & 0.74 & 0.76 & 0.74 & 0.74 \\
\hline Digestible Valine (\%) & 0.90 & 0.88 & 0.88 & 0.90 & 0.88 & 0.88 \\
\hline Total Calcium (\%) & 0.90 & 0.75 & 0.75 & 0.90 & 0.75 & 0.75 \\
\hline Available Phosphorus (\%) & 0.45 & 0.30 & 0.30 & 0.45 & 0.30 & 0.30 \\
\hline
\end{tabular}

* T1, control diet with conventional feedstuffs; T2, T1 with nutritional reduction (metabolizable energy, digestible amino acids, phosphorus and calcium); T3, T2 with multi-enzyme complex; $\mathrm{T4}$, control diet with alternative feedstuffs; $\mathrm{T5}$, $\mathrm{T4}$ with nutritional reduction; $\mathrm{T6}, \mathrm{T} 5$ with multi-enzyme complex.

** Rovabio MAX AP, Adisseo France SAS

*** Supplemented per kilogram of premix: biotin, $0.03 \mathrm{mg}$; choline, $385.55 \mathrm{mg}$; copper, $24.8 \mathrm{mg}$; folic acid, $0.69 \mathrm{mg}$; iodine, $3.31 \mathrm{mg}$; iron, $110.25 \mathrm{mg}$; manganese, $220.5 \mathrm{mg}$; niacin, $27.56 \mathrm{mg}$; pantothenic acid, $6.62 \mathrm{mg}$; selenium, $0.33 \mathrm{mg}$; thiamin $3.31 \mathrm{mg}$; vitamin A, 7,717.5 IU; vitamin B12B, $0.01 \mathrm{mg}$; vitamin B6, 1.38 mg; vitamin D3, 2, $103.75 \mathrm{ICU}$; vitamin E, $16.54 \mathrm{IU}$; vitamin K, $0.83 \mathrm{mg}$; zinc, $220.5 \mathrm{mg}$. Monensin sodium, $110 \mathrm{~g} /$ ton; Bacitracin methylene disalicylate, $50 \mathrm{~g} / \mathrm{ton}$.

unit (12 broilers/treatment) were killed by cervical dislocation. The small intestine was removed and fragments measuring approximately $5 \mathrm{~cm}$ long were taken from the duodenum, jejunum and ileum. Each fragment was semi-serially sectioned ( $5 \mu \mathrm{m}$ thick) and then stained with hematoxylin and eosin (HE). Stained slides allowed assessing microscopic injuries and the scoring $(0,1,2$ or 3$)$ of the lesions of the epithelium and lamina propria of the mucosa, presence of edema, hemorrhage, polymorphonuclear neutrophils and dilated lymphatics vessels.

In order to quantify goblet cells, slides with ileum fragments were stained with $\mathrm{HE}$ and Alcian Blue, and subsequently marked by the immunohistochemical technique with Anti-CD3 primary antibody (CD3 Dako 1:750). We quantified ten microscopic fields/slide under light microscopy (Olympus America Inc., NY), with 100x magnification for each fragment.
Statistical analysis of data was undertaken by means of the GLM procedure of SAS. Since the data did not present normal distribution, data relative to microscopic lesions of the intestinal mucosa were analyzed by the Kruskal-Wallis non-parametric test (SAS, 1998).

\section{RESULTS AND DISCUSSION}

The feeding of diets containing conventional or alternative feedstuffs, added or not with enzymes, had no influence on the percentage of microscopic lesions in the mucosa in none of the intestinal segments examined (Tables 4 and 5). On the other hand, there was a higher incidence of lesions for alternative ingredients, regardless the nutritional density. These lesions, located in the luminal epithelium and lamina propria of the mucosa, occurred more often in the jejunum and ileum. The alternative feedstuffs used, besides being 
Table 3 - Composition and nutritional levels of the grower diets.

\begin{tabular}{|c|c|c|c|c|c|c|}
\hline Ingredients & T1* & $\mathrm{T} 2$ & T3 & T4 & T5 & T6 \\
\hline Corn & 55.35 & 58.32 & 58.32 & 22.72 & 24.63 & 24.63 \\
\hline Millet & - & - & - & 22.56 & 24.43 & 24.43 \\
\hline Soybean meal & 35.71 & 34.35 & 34.35 & 21.16 & 20.36 & 20.36 \\
\hline Sunflower meal & - & - & - & 10.58 & 10.18 & 10.18 \\
\hline Canola meal & - & - & - & 10.58 & 10.18 & 10.18 \\
\hline Soybean oil & 5.17 & 4.19 & 4.19 & 8.77 & 7.16 & 7.16 \\
\hline Limestone & 0.95 & 1.14 & 1.14 & 0.88 & 1.08 & 1.08 \\
\hline Dicalcium phosphate & 1.52 & 0.69 & 0.69 & 1.34 & 0.52 & 0.52 \\
\hline Salt & 0.39 & 0.40 & 0.40 & 0.37 & 0.39 & 0.39 \\
\hline L-Lysine 78\% & 0.16 & 0.17 & 0.17 & 0.36 & 0.36 & 0.36 \\
\hline DL-Methionine 99\% & 0.29 & 0.29 & 0.29 & 0.23 & 0.23 & 0.23 \\
\hline L-Threonine 98\% & 0.06 & 0.06 & 0.06 & 0.10 & 0.10 & 0.10 \\
\hline Multi-enzyme complex** & - & - & 0.10 & - & - & 0.10 \\
\hline Inert material & - & 0.10 & - & - & 0.10 & - \\
\hline Vitamin and Mineral Premix*** & 0.40 & 0.40 & 0.40 & 0.40 & 0.40 & 0.40 \\
\hline Metabolizable Energy (kcal/kg) & 3.175 & 3.090 & 3.090 & 3.175 & 3.090 & 3.090 \\
\hline Crude Protein (\%) & 20.62 & 20.21 & 20.21 & 19.69 & 19.30 & 19.30 \\
\hline Crude Fiber (\%) & 2.89 & 2.88 & 2.88 & 5.80 & 5.74 & 5.74 \\
\hline Crude Fat (\%) & 7.57 & 6.70 & 6.70 & 10.08 & 8.62 & 8.62 \\
\hline Digestible Lysine (\%) & 1.05 & 1.03 & 1.03 & 1.05 & 1.03 & 1.03 \\
\hline Digestible Met + Cis (\%) & 0.78 & 0.76 & 0.76 & 0.78 & 0.76 & 0.76 \\
\hline Digestible Threonine (\%) & 0.68 & 0.67 & 0.67 & 0.68 & 0.67 & 0.67 \\
\hline Digestible Valine (\%) & 0.81 & 0.79 & 0.79 & 0.81 & 0.79 & 0.79 \\
\hline Total Calcium (\%) & 0.80 & 0.65 & 0.65 & 0.80 & 0.65 & 0.65 \\
\hline Available Phosphorus (\%) & 0.40 & 0.25 & 0.25 & 0.40 & 0.25 & 0.25 \\
\hline
\end{tabular}

* T1, control diet with conventional feedstuffs; T2, T1 with nutritional reduction (metabolizable energy, digestible amino acids, phosphorus and calcium); T3, T2 with multi-complex enzyme; T4, control diet with alternative feedstuffs; T5, T4 with nutritional reduction; T6, T5 with multi-enzyme complex.

** Rovabio MAX AP, Adisseo France SAS

*** Supplemented per kilogram of premix: biotin, 0.03 mg; choline, 385.55 mg; copper, 24.8 mg; folic acid, 0.69 mg; iodine, 3.31 mg; iron, 110.25 mg; manganese, 220.5 mg; niacin, 27.56 mg; pantothenic acid, 6.62 mg; selenium, 0.33 mg; thiamin 3.31 mg; vitamin A, 7,717.5 IU; vitamin B12B, 0.01 mg; vitamin B6, 1.38 mg; vitamin D3, 2, 103.75 ICU; vitamin E, $16.54 \mathrm{IU}$; vitamin K, $0.83 \mathrm{mg}$; zinc, $220.5 \mathrm{mg}$. Monensin sodium, $110 \mathrm{~g} / \mathrm{ton}$; Bacitracin methylene disalicylate, $50 \mathrm{~g} / \mathrm{ton}$.

more abrasive, are richer in non-digestible fiber for poultry, becoming thus substrate for the development of microorganisms at the end of the small intestine. The use of non-digestible substrates by bacteria causes adverse effects on the intestinal mucosa, in addition of villus atrophy in the intestinal mucosa.
The digestive system is naturally in permanent contact with agents and substances from the external environment. In addition of its primary role and importance in digestion and absorption of nutrients, the gastrointestinal mucosa represents a gateway to dietary antigens and non-pathogenic bacterial

Table 4 - Percentage of microscopic lesion scores in intestinal segments of 42-d-old broilers fed conventional or alternative diets, supplemented or not with an multi-enzyme complex.

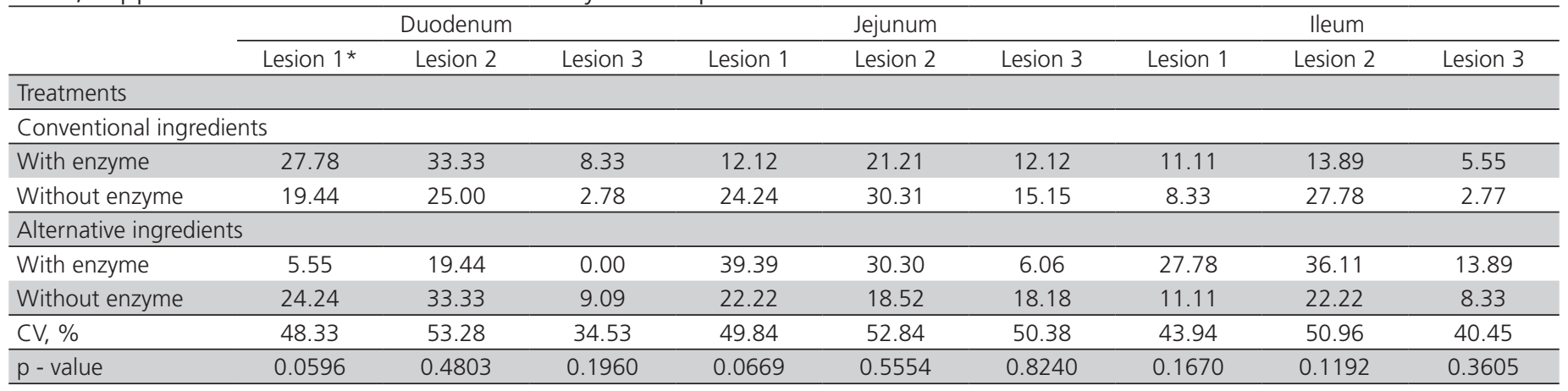

\footnotetext{
* 1. Lesion of the epithelium and lamina propria of the mucosa, 2. Presence of edema, hemorrhage, polymorphonuclear neutrophils, 3. Dilated lymphatics vessels.
} 
Table 5 - Percentage of microscopic lesion scores in intestinal segments of 42 -d-old broilers fed conventional or alternative diets with normal or reduced nutritional density.

\begin{tabular}{|c|c|c|c|c|c|c|c|c|c|}
\hline & \multicolumn{3}{|c|}{ Duodenum } & \multicolumn{3}{|c|}{ Jejunum } & \multicolumn{3}{|c|}{ Ileum } \\
\hline & Lesion 1* & Lesion 2 & Lesion 3 & Lesion 1 & Lesion 2 & Lesion 3 & Lesion 1 & Lesion 2 & Lesion \\
\hline \multicolumn{10}{|l|}{ Treatments } \\
\hline \multicolumn{10}{|c|}{ Conventional ingredients } \\
\hline Normal density & $8.33 a b$ & 27.77 & 2.78 & $21.21 \mathrm{ab}$ & $24.24 a b$ & 9.09 & $5.55 b$ & 27.78 & 2.78 \\
\hline Reduced density & $27.78 a$ & 33.33 & 8.33 & $12.12 \mathrm{~b}$ & $12.21 \mathrm{~b}$ & 12.12 & 11.11ab & 13.90 & 5.55 \\
\hline \multicolumn{10}{|c|}{ Alternative ingredients } \\
\hline Normal density & $27.78 a$ & 33.33 & 8.33 & $27.27 a b$ & $12.12 b$ & 6.06 & $27.78 a$ & 38.89 & 5.55 \\
\hline Reduced density & $5.55 b$ & 19.44 & 0.00 & $39.39 a$ & $30.30 a$ & 18.18 & $27.78 a$ & 36.11 & 13.89 \\
\hline$C V, \%$ & 45.27 & 50.56 & 37.87 & 48.80 & 52.10 & 46.67 & 47.52 & 50.20 & 38.81 \\
\hline$p$-value & 0.0073 & 0.3585 & 0.2218 & 0.0493 & 0.4476 & 0.5038 & 0.0335 & 0.0651 & 0.3209 \\
\hline
\end{tabular}

microflora, which are a strong source of disturbance for the immune activity in the organism (Berg, 1999). Therefore, the intestinal mucosa should have adequate structural morphophysiological characteristics. The absorption process is dependent on transport mechanisms that occur in the membrane of epithelial cells of the mucosa, and thus their integrity is essential, since this is the route of entry of nutrients used for broiler development.

The amount of cells positive for CD3 (CD3+) in the mucosa of the ileum was significantly different $(p<0.05)$, when conventional and alternative feedstuffs are compared (Tables 6 and 7). Broilers fed diets based on corn and soybeans presented higher amounts of these defense cells than those fed the diets that included fibrous ingredients.

Table 6 - Quantification of $\mathrm{CD}^{+}$cells and goblet cell counts in the mucosa of the ileum of broilers, and serum electrophoretic profile of immunoglobulin A $(\lg A)$ of broilers fed conventional or alternative diets supplemented or not with an multi-enzyme complex.

\begin{tabular}{|c|c|c|c|}
\hline \multirow{2}{*}{ Treatments } & \multicolumn{2}{|c|}{ Ileal mucosa } & \multirow{2}{*}{$\frac{\text { Serum }}{\operatorname{lgA}(g / d L}$} \\
\hline & CD3+ & Goblet cells & \\
\hline \multicolumn{4}{|l|}{ Diets } \\
\hline $\begin{array}{l}\text { Conventional } \\
\text { ingredients }\end{array}$ & $94.95^{\mathrm{a}}$ & $51.28^{a}$ & 0.103 \\
\hline Alternative ingredients & $92.14 b$ & $39.41 \mathrm{~b}$ & 0.108 \\
\hline \multicolumn{4}{|l|}{ Enzyme } \\
\hline With enzyme inclusion & $94.57^{a}$ & 43.20 & 0.105 \\
\hline $\begin{array}{l}\text { With no enzyme } \\
\text { inclusion }\end{array}$ & $92.52 b$ & 47.97 & 0.106 \\
\hline$C V, \%$ & 2.63 & 19.09 & 36.66 \\
\hline \multicolumn{4}{|l|}{$p$ - values } \\
\hline Ingredients & 0.0111 & 0.0031 & 0.9325 \\
\hline Enzyme & 0.0500 & 0.2388 & 0.2659 \\
\hline Interaction & 0.5730 & 0.2477 & 0.8713 \\
\hline
\end{tabular}

Means of a same factor followed by different letters indicate significant effect $(p<0.05)$ of treatments by the Fisher LSD test. No interactions between the factors tested were observed ( $p>0.05)$.
The inclusion of enzymes in conventional or alternative diets reduced $(p<0.05)$ the number of CD3 in the mucosa of the ileum. These cells, counted using immunohistochemical analysis, are supposed to be $T$ lymphocytes, because $T$ lymphocytes present molecules that are expressed on their surface, called cell determinants (CD). CD3 is expressed by all lymphocytes at their origin and remains present throughout the life of cells, being a surface antigen common of $T$ lymphocytes (Barua \& Yoshimura, 2004). CD3 is the best marker for total $\mathrm{T}$ lymphocyte count, because it is a molecular complex associated with specific receptors of $\mathrm{T}$ lymphocytes and is found in all subpopulations of mature T cells.

Table 7 - Quantification of $\mathrm{CD}^{+}$cells and count of goblet cells in the mucosa of the ileum of broilers and serum electrophoretic profile of immunoglobulin A (IgA) of broilers fed conventional or alternative diets, and with normal or reduced nutritional density.

\begin{tabular}{lccc}
\hline & \multicolumn{2}{c}{ lleal mucosa } & Serum \\
\hline Treatments & CD3 & Goblet & $\operatorname{lgA}(\mathrm{g} / \mathrm{dL})$ \\
\hline Diets & & & \\
\hline $\begin{array}{l}\text { Conventional } \\
\text { ingredients }\end{array}$ & $97.66^{\mathrm{a}}$ & $48.87^{\mathrm{a}}$ & 0.112 \\
\hline $\begin{array}{l}\text { Alternative ingredients } \\
\text { Nutritional density }\end{array}$ & $93.19 \mathrm{~b}$ & $41.65 \mathrm{~b}$ & 0.108 \\
\hline Normal & 96.28 & 47.32 & 0.105 \\
\hline Reduced & 94.57 & 43.20 & 0.114 \\
\hline CV, \% & 3.94 & 19.16 & 35.93 \\
\hline P-values & & \\
\hline Ingredients & 0.0087 & 0.0500 & 0.8518 \\
\hline Nutritional density & 0.2773 & 0.2575 & 0.2147 \\
\hline Interaction & 0.1618 & 0.9019 & 0.6857 \\
\hline
\end{tabular}

Means of a same factor followed by different letters indicate significant effect $(p<0.05)$ of treatments by the Fisher LSD test. No interactions between the factors tested were observed $(p>0.05)$. 
Soybeans have a significant amount NSP in the form of pectins, hemicelluloses and oligosaccharides (stachyose and raffinose). Out of these NSP, 20\% have null digestibility, and $2 \%$ are xylans (Cleophas et al., 1995). The tissue defense triggered against an infection basically consists of three mechanisms, which frequently act according to a chronological sequence. This protective mechanism consists of non-induced innate defense, induced innate defense and adaptive immune response. The cellular immune response in the intestinal mucosa is mainly composed of T-CD3 and T-CD4 lymphocytes.

Corroborating this hypothesis, we verified an increase $(p<0.05)$ in the number of goblet cells in conventional diets. These cells are responsible for the production of a mucous layer mainly consisting of glycoproteins, known as mucins, which contain a long polysaccharide portion that makes them hydrophilic and viscous. The functions of mucins include protection of the brush border membrane from chemicals and from the abrasive effects of the digesta. They act as a barrier against microorganisms, because the natural intestinal flora and immunoglobulins are included in the mucus layer, and influence the transport between the luminal content and the brush border membrane (Snyder \& Walker, 1987; Uni et al., 2003).

The hyperplasia and/or hypertrophy of goblet cells in the small intestine are considered as a response to some type of aggression, aiming at maintaining mucosal integrity. Several studies (Mitjavila et al., 1977; Ortiz et al., 1994; Oliveira et al., 2000; Uni et al., 2003) have reported this effect in response to antinutritional factors of feedstuffs or delay in supplying feed after hatching, for instance.

Teirlynck et al. (2009) mentioned that the inclusion of ingredients such as wheat and rye in the diet for broilers - thus containing high levels of NSP - in comparison with a diet based on corn, induces the fusion of intestinal villi, infiltration of T lymphocytes, hyperplasia and hypertrophy of goblet cells, apoptosis of epithelial cells in the mucosa, and shifts in the microbiota. In the present experiment, the supplementation of enzymes or the reduction of the nutritional density of diets, independently of the feedstuffs used, did not influence the number of goblet cells.

Mucin production may increase in the presence of biologically-active proteins, aiming at protecting the intestinal epithelium. However, mucin significantly contributs to the endogenous loss in chickens (Montagne et al., 2000). This hypothesis is supported by the fact that amino acids that compose the intestinal mucin are excreted in response to the addition of enzymes (Cowieson et al., 2006).

Serum IgA immunoglobulin electrophoretic profile was not affected by the ingredients used in the diets, supplemented or not with enzyme complex, and with reduction or not of the nutritional density. The immune stimulation of the mucosa results in the production of $\lg \mathrm{A}$ antibodies that block the receptors and reduce the number of pathogenic bacteria in the intestinal lumen (Jin et al., 1997). Despite the increase in lymphocytes observed, as shown by the marker CD3, no IgA increase was observed in the serum of broilers.

IgA is especially produced by B-cells located on the intestinal lamina propria and has a key role in the maintenance of homeostasis of the intestinal mucosa. Dendritic cells that present the antigens from commensal bacteria of the intestinal mucosal surface induce the production of $\operatorname{lgA}$ by B-cells through mechanisms dependent or not of $T$ cells. Notwithstanding it is well documented that IgA production is induced by bacterial colonization, the kinetics and duration of this response, as well as possible ways of inducing it have not yet been fully elucidated (Tezuka et al., 2011).

Jackson et al. (2003) reported that in chickens infected with Eimeria $s p$ and Clostridium perfringens the addition of $\beta$-mananase resulted in the reduction of the severity of the challenge generated by these microorganisms, and this effect was observed not only as increased body weight, but also as a reduction of intestinal lesions. However, Mushtaq et al. (2007) added glucanase and xylanase in diets based on canola meal, and did not record any benefits in terms of performance, nutrient digestibility, immune response, or carcass characteristics of broilers.

\section{CONCLUSIONS}

The use of alternative plant feedstuffs in broiler diets promoted an increase in intestinal lesions and enhanced cellular immune response. However, this undesirable gut health condition can be mitigated to a certain degree, as found with the use of conventional corn and soybean meal diets, by using a multi-enzyme complex.

\section{ACKNOWLEDGMENTS}

The authors would like to thank Adisseo Brazil Animal Nutrition Ltd. for funding the present research study and the PENA study group of the Federal University of Paraná, Palotina campus, for conducting and analyzing of this experiment. 


\section{REFERENCES}

Barua A, Yoshimura Y. Ovarian cell-mediated immune response to Salmonella Enteritidis infection in laying hens (Gallus domesticus). Poultry Science 2004;83(6):997-1002.

Berg RD. Bacterial translocation from the gastrointestinal tract. Advances in Experimental Medicine and Biology 1999;473:11-30.

Campbell GL, Classen HL, Goldsmith KA. Effect of fat retention on the rachitogenic effect of rye fed to broiler chicks. Poultry Science $1983 ; 62(11): 2218-2213$.

Choct M, Dersjant-Li Y, McLeish J, Peisker M. Soy oligosaccharides and soluble non-starch polysaccharides: a review of digestion, nutritive and anti-nutritive effects in pigs and poultry. Asian-Australian Journal of Animal Science 2010;23(10):1386-1398.

Choct M, Hughes RJ, Wang J, Bedford MR, Morgan AJ, Annison G. Increased small intestinal fermentation is partly responsible for the anti-nutritive activity of non-starch polysaccharides in chickens. British Poultry Science 1996;37(3):609-621.

Choct M, Kocher A, Waters DLE, Petterson D, Ross G. A comparison of three xylanases on the nutritive value of two wheat's for broiler chickens. British Journal of Nutrition 2004;92:53-61.

Cleophas GML, Van Hartingsveldt W, Somers WAC. Enzymes can play an important role in poultry nutrition. World Poultry 1995;11(4):12-15.

Cowieson AJ, Acamovic T, Bedford MR. Using the precision-feeding bioassay to determine the efficacy of exogenous enzymes: a new perspective. Animal Feed Science and Technology 2006;129(1-2):149-158.

Fang ZF, Peng J, Liu ZL, Liu YG. Responses of non-starch polysaccharidedegrading enzymes on digestibility and performance of growing pigs fed a diet based on corn, soya bean meal and Chinese double-low rapeseed meal. Journal of Animal Physiology and Animal Nutrition 2007;91(7):361-368

Farrell DJ. Matching poultry production with available feed resources: issues and constraints. World's Poultry Science Journal 2005;61(2):298-307.

Högberg A, Lindberg JE. Influence of cereal non-starch polysaccharides an enzymes supplementation on digestion site and gut environment in weaned piglets. Animal Feed Science and Technology 2004;116(12):113-128

Humphrey BD, Klasing KC. Modulation of nutrient metabolism and homeostasis by the immune system. World's Poultry Science Journal 2007;60(1):90-100

Jackson ME, Anderson DM, Hsiao HY, Mathis GF, Fodge DW. Beneficial effect of $\beta$-mannanase feed enzyme on performance of chicks challenged with Eimeria sp. and Clostridium perfringens. Avian Diseases 2003;47(3):759-763.

Jia W, Slominski BA, Bruce HL, Blank G, Crow G, Jones O. Effects of diet type and enzyme addition on growth performance and gut health of broiler chickens during subclinical Clostridium perfringens challenge. Poultry Science 2009;88(1):132-140

Jin LZ, Ho YW, Abdullah N, Jalaluddin S. Probiotics in poultry: modes of action. World's Poultry Science Journal 1997;53(4):351-368.

Kim JC, Simmins PH, Mullan BP, Pluske JR. The digestible energy value of wheat for pigs, with special reference to the post-weaned animal. Animal Feed Science and Technology 2005;122(3-4):257-287

Kocher A, Choct M. Porter D, Broz J. The effects of enzyme addition to broiler diets containing high concentrations of canola or sunflower meal. Poultry Science 2000; 79(12):1767-1774.
Lee SY, Kim JS, Kim JM, An BK, Kang CW. Effects of multiple enzyme (Rovabio Max) containing carbohydrolases and phytase on growth performance and intestinal viscosity in broiler chicks fed corn-wheatsoybean meal based diets. Asian-Australian Journal of Animal Science 2010;23(9):1198-1204.

Lentle RG, Janssen PW, Asvarujanon P. High definition mapping of circular and longitudinal motility in the terminal ileum of the brushtail possum Trichosurus vulpecula with watery and viscous perfusates. Journal of Comparative Physiology 2007;177(5):543-556

Lentle RG, Janssen PW. Physical characteristics of digesta and their influence on flow and mixing in the mammalian intestine: a review. Journal of Comparative Physiology 2008; 178(6):673-690

Macari M, Furlan RL, Gonzales E. Fisiologia aviária aplicada a frangos de corte. Jaboticabal: FUNEP-UNESP; 2002.

Maciel RM, Lopes STA, Santurio JM, Rosa AP, Duarte MMMF, Martins DB, Emanuelli MP. Electrophoresis profile of serum proteins in broilers fed with diets containing aflatoxins and/or natural clinoptilolite clay. Ciência Rural 2007;37(3):744-749.

Maisonnier S, Gomez J, Chagneau AM, Carré B. Analysis of variability in nutrient digestibilities in broiler chickens. British Poultry Science $2001 ; 42(1): 70-76$

Meng X, Slominski BA, Nyachoti CM, Campbell LD, Guenter W. Degradation of cell wall polysaccharides by combinations of carbohydrase enzymes and their effect on nutrient utilization and broiler chicken performance. Poultry Science 2005;84(1):37-47

Mitjavila S, Lacombe C, Carrera G, Derache R. Tannic acid and oxidized tannic acid on the functional state of rat intestinal epithelium. Journal of Nutrition 1977;107(12):2113-2121.

Montagne L, Toullec R, Lalles JP. Calf intestinal mucin: isolation, partial characterization, and measurement in ileal digesta with an enzyme-linked immunosorbent assay. Journal of Dairy Science 2000;83(3):507-517.

Montanhini RN, Ceccantini ML, Fernandes JIM. Productive performance, intestinal morphology and carcass yield of broilers fed conventional and alternative diets containing commercial enzymatic complex. International Journal of Poultry Science 2012;11(8):505-516.

Mushtaq T, Sarwar M, Ahmad G, Mirza MA, Nawaz H, Mushtaq MMH Noreen $U$. Influence of canola meal-based diets supplemented with exogenous enzyme and digestible lysine on performance, digestibility, carcass, and immunity responses of broiler chickens. Poultry Science 2007;86(10):2144-2151.

Odetallah HN, Ferket PR, Grimes JL, Mcnaughton JL. Effect of mannanendo-1,4- $\beta$-mannosidade on the growth performance of turkeys fed diets containing 44 and $48 \%$ crude protein soybean meal. Poultry Science 2002;81(9):1322-1331

Oliveira MC, Moraes VMB. Mannan oligosaccharides and enzymes in corn and soybean meal based-diets for broilers. Ciência Animal Brasileira 2007;8(3):339-357

Oliveira PB, Murakami AE, Garcia ERM, Macari M, Scapinello C. Influence of antinutritional factors of leucena (Leucaena leucocephala and Leucaena cunningan) and pigeous bean (Cajanus cajan) on the intestinal epithelium and performance of broiler chickens. Revista Brasileira de Zootecnia 2000;29(6):1759-1769.

Ortiz LT, Alzueta C, Treviño J, Castaño M. Effects of faba bean tannins on the growth and histological structure of the intestinal tract and liver of chicks and rats. British Poultry Science 1994;35(5):743-754.

Peng SY, Norman J, Curtin G, Corrier D, McDaniel HR, Busbee D. Decreased mortality of Norman murine sarcoma in mice treated with the immunomodulator, Acemannan. MolecularBiotherapy 1991;3(2):79-87. 


\section{Alternative Diets Containing Multi-Enzyme Complex}

Ramos LSN, Lopes JB, Figueiredo AV, Alves AA. Use of exogenous enzymes in diets of broilers chickens. Revista Científica de Produção Animal 2007;9(1):84-94

Ross SA, Duncan CJG, Pasco DS, Pugh N. Isolation of a galactomannan that enhances macrophage activation from the edible fungus Morchella esculenta. Journal of Agricultural and Food Chemistry 2002;50(20):5683-5685

Rostagno HS. Tabelas brasileiras para aves e suínos: composição de alimentos e exigências nutricionais. $3^{a}$ Ed. Viçosa: Universidade Federal de Viçosa; 2011. 252p.

Rutherfurd SM, Chung TK, Moughant PJ. The effect of a commercial enzyme preparation on apparent metabolizable energy, the ileal amino acid digestibility, and endogenous ileal lysine losses in broiler chickens. Poultry Science 2007;86(4):665-672.

Statistical Analysis System. Cary: SAS Institute; 1998

Shirmohammad F, Mehr M. Effects of dietary supplementation of multienzyme complex on the energy utilization in rooster and performance of broiler chicks. African Journal of Biotechnology 2011;10(45):92009206.

Snyder JD, Walker A. Structure and function of intestinal mucin: developmental aspects. International Archives of Allergy and Applied Immunology 1987;82(3-4):351-356.
Steenfeldt S, Hammershoj M, Mullertz A, Jensen F. Enzyme supplementation of wheat-based diets for broilers: 2. Effect on apparent metabolizable energy content and nutrient digestibility. Animal Feed Science and Technology 1998;75(1):45-64.

Teirlynck E, Bjerrum L, Eeckhaut V, Huygebaert G, Pasmans F, Haesebrouck F, Dewulf J, Ducatelle R, Immerseel FV. The cereal type in feed influences gut wall morphology and intestinal immune cell infiltration in broiler chickens. British Journal of Nutrition 2009; 102(10):1453-1461.

Tezuka H, Abe Y, Asano J, Sato T, Liu J, Iwata M, Ohteki T. Prominent role of plasmocytoid dendritic cells in mucosal $T$ cell-independent $\lg A$ induction. Immunity 2011;34(2):247-257.

Uni Z, Smirnov A, Skalan D. Pre and posthatch of development of goblet cells in the broiler small intestine: effect of delayed access to feed. Poultry Science 2003;82(2):320-327.

Woyengo TA, Slominski BA, Jones RO. Growth performance and nutrient utilization of broiler chickens fed diets supplemented with phytase alone or in combination with citric acid and multicarbohydrase. Poultry Science 2010;89(10):2221-2229.

Zhang L, Tizzard IR. Activation of a mouse macrophage cell line by acemannan: the major carbohydrate fraction from Aloe vera gel. Immunopharmacology 1996;35(2):119-128. 